\title{
New Drugs?
}

\section{G. Pellegrini}

Department of Surgery, Medicine, Dentistry, and Morphological Sciences, University of Modena and

Reggio Emilia, Modena, Italy

E-mail: grzllpellegrini@gmail.com

In 2007, the European pharmacology opened an avenue to a new category of medicinal products, the ATMPs (Advanced Therapy Medicinal Products).

What are they?

The ATMPs are living drugs as most of them are composed of live cells or tissues.

Indeed, in vitro cultured tissue or organ or genetically modified cells are now considered medicines. An issue associated with these products is that human cell-based therapies include complex biological products sensitive to their environment. Moreover, the final products maintain the intrinsic variability of the human donors. Additionally, they have a short shelf life, and it is difficult to achieve the required release control and identify controllable parameters related to clinical efficacy (the potency), as "living medicines" act via multiple mechanisms in the pathologic environment $(1,2)$.

Like any other drug, ATMPs must undergo safety evaluations, and the use of animal models is a concern, because of the anatomical and physiological differences between humans and the animal models. This makes surgery and immunological evaluations difficult or not comparable to humans.

Moreover, in clinical trials, it is difficult to define the control group or randomise patients to administer these drugs, as it requires surgery, which is not ethically acceptable without a positive benefit-to-risk ratio in humans.

On the contrary, all medicine guidelines necessitate a tightly regulated GMP (Good Manufacturing Practices) and GCP (Good Clinical Practices) (3).

The regulation of these products is desirable to avoid adverse events, possibly related to the extensive manipulation of cells and tissues with different substances. The guidelines originally proposed for ATMPs were the same applied to standard drugs, which are not fit for manufacturing and regulating these living organisms as they are mobile and change with time. Several adjustments to the regulations were required to better define how to produce and monitor these products. One of the most interesting approaches is the ICHQ8 guideline on "Quality by design", reproducing biologists' evaluations in cell/tissue cultures by correlating different parameters to define an area where a product complies with specifications. It also allows the maintenance of quality by necessary modifications of the manufacturing process parameters.

Some ATMPs have been registered in Europe, highlighting how at least some of these products can fit in the regulatory guidelines $(4,5)$.

As any new path, ATMPs offer a transformative approach to healthcare, with the potential to not only treat, but often cure diseases.

They also provide a great opportunity for industries, as they are a new category of exploitable products with economic benefits, once the industry acquires sufficient knowledge (7).

However, the industrialisation approach has not been fully developed, as it requires implementation of approaches that are different from those of other industrial fields. 
Indeed, the production and efficacy of these products is strictly related to the mode of administration and the subsequent patient health care, placing them in an intermediate position between drugs and transplants.

The implementation of bedside to bench and back again approach would focus on specific unmet clinical needs, defining critical translation requirements, as well as increasing opportunity for the future reimbursement, early in the research $(8,9)$.

From an industrial point of view, there are some additional issues associated with these products. For example, mass production requiring large-scale production necessitates at least partial robotisation of the process.

The automation of living cells is feasible, but it requires deep knowledge to monitor cell metabolism and reactions to any stimuli $(10,11)$.

As previously mentioned, the ATMPs comprise the whole treatment, from the starting material, which is obtained from humans, to in-process controls and administration by surgery.

This implies that healthcare personnel should be educated with this type of treatments, with specific training by cell biologists. Moreover, an ATMP cannot be just proposed by pharmaceutical representatives (1214).

There is some scepticism. People frequently speak about valley of death (15).

The history of aeronautics was not easy, as well, but there is no doubt about the importance of previous studies to the present scenario.

Several ATMPs have been efficiently translated in clinical practice, from cell to gene therapy, showing positive results for several pathologies (16).

After more than 10 years, the path is still steep, but not unachievable; the applied regulations have been progressively adapted to the new needs and the ICHQ8 rules introduced the concept of quality by design, which is probably the best approach for this type of products when sufficient information is available.

In biology, there is a strict interconnection between several parameters that should be considered together, and not individually, by several single specification limits.

Optimisation of the cost-to-benefit ratio of several controls requested by regulatory authorities should be achieved. Fortunately, increasing cross talk between biologists and regulators will speed up the bilateral learning process.

The automation of these processes is moving towards modular approaches, enabling the adaptation of multiple processes and products.

An additional interesting opportunity from this new category of drugs that is still under-evaluated, is its link with pharmacology.

The traditional non-clinical pharmacology, including pharmacokinetics and toxicity studies, cannot be employed for most ATMPs, offering a new opportunity for both biologists and pharmacologists to upgrade them; for example, new approaches for cell/tissue preclinical testing, development of new in vitro human tissues, co-culture of different cell types, organs on chip, and new approaches to immunology. They can be used as new models for standard drug testing more specific for humans, providing more information on various cell alterations. The data generated by collaboration between pharmacologists and tissue engineers will speed up research in both fields, supporting mechanistic evaluation of medicines in humans.

This new cooperation should be improved not only to provide a wide range of opportunities, but also to gain access to precision medicine by cutting-edge science and new technologies.

\section{Conflict of Interest}

I have no conflict of interests and the opinions are of my own.

\section{References}

1. Challenges with advanced therapy medicinal products and how to meet them.Committee for Advanced Therapies (CAT); CAT Scientific Secretariat, Schneider CK, Salmikangas P, Jilma B, Flamion B, Todorova LR, Paphitou A, Haunerova I, Maimets T, Trouvin JH, Flory E, Tsiftsoglou A, Sarkadi B, Gudmundsson K, O'Donovan M, Migliaccio G, Ancāns J, Maciulaitis R, Robert JL, Samuel A, Ovelgönne JH, Hystad M, Fal AM, Lima BS, Moraru AS, Turcáni P, Zorec R, Ruiz S, Akerblom L, Narayanan G, Kent A, Bignami F, Dickson JG, Niederwieser D, Figuerola-Santos MA, Reischl IG, Beuneu C, Georgiev R, Vassiliou M, Pychova A, Clausen M, Methuen T, Lucas S, Schüssler-Lenz M, Kokkas V, Buzás Z, MacAleenan N, Galli MC, Linē A, Gulbinovic J, Berchem G, Fraczek M, Menezes-Ferreira M, Vilceanu N, Hrubisko M, Marinko P, Timón M, Cheng W, Crosbie GA, Meade N, di Paola ML, VandenDriessche T, Ljungman P, D'Apote L, Oliver-Diaz O, Büttel I, Celis P. Nat Rev Drug Discov. 2010 Mar;9(3):195-201.

2. Approaches for Effective Clinical Application of Stem Cell Transplantation. Attico E, Sceberras V, Pellegrini G. Curr Transplant Rep. 2018;5(3):244-250. 
3. Skin regeneration: the complexities of translation into clinical practise. Wood FM. Int J Biochem Cell Biol. 2014 Nov;56:13340.

4. Navigating Market Authorization: The Path Holoclar Took to Become the First Stem Cell Product Approved in the European Union. Pellegrini G, Ardigò D, Milazzo G, Iotti G, Guatelli P, Pelosi D, De Luca M. Stem Cells Transl Med. 2018 Jan;7(1):146-54

5. Aiuti A, Roncarolo MG, Naldini L, Gene therapy for ADASCID, the first marketing approval of an ex vivo gene therapy in Europe: paving the road for the next generation of advanced therapy medicinal products. EMBO Mol Med. 2017.

6. Beyond the Present Constraints That Prevent a Wide Spread of Tissue Engineering and Regenerative Medicine Approaches. O'Donnell BT, Ives CJ, Mohiuddin OA, Bunnell BA. Front Bioeng Biotechnol. 2019 May7;7:95.

7. Advanced Therapy Medicinal Products for Rare Diseases: State of Play of Incentives Supporting Development in Europe. Farkas AM, Mariz S, Stoyanova-Beninska V, Celis P, Vamvakas S, Larsson K, Sepodes B. Front Med (Lausanne). 2017 May16;4:53.

8. Regulatory Considerations for Gene Therapy Products in the US, EU, and Japan. Halioua-Haubold CL, Peyer JG, Smith JA, Arshad Z, Scholz M, Brindley DA, MacLaren RE. Yale J Biol Med. 2017 Dec 19;90(4):683-693.

9. Addressing Pressing Needs in the Development of Advanced Therapies. Morrow D, Ussi A, Migliaccio G. Front Bioeng Biotechnol. 2017 Sep25;5:55.

10. Design and Validation of an Automated Process for the Expansion of Peripheral Blood-Derived CD34+Cells for Clinical Use After Myocardial Infarction. Saucourt C, Vogt S, Merlin A, Valat C, Criquet A, Harmand L, Birebent B, Rouard H, Himmelspach C, Jeandidier É, Chartois-Leauté AG, Derenne S, Koehl L, Salem JE, Hulot JS, Tancredi C, Aries A, Judé S, Martel E, Richard S, Douay L, Hénon P. Stem Cells Transl Med. 2019 Apr 29.
11. Qualification of academic facilities for small-scale automated manufacture of autologous cell-based products. Hourd P, Chandra A, Alvey D, Ginty P, McCall M, Ratcliffe E, Rayment E, Williams DJ. Regen Med. 2014;9(6):799-815.

12. Marketing Regulatory Oversight of Advanced Therapy Medicinal Products (ATMPs) in Europe: The EMA/CAT Perspective. Salmikangas P, Schuessler-Lenz M, Ruiz S, Celis P, Reischl I, Menezes-Ferreira M, Flory E, Renner M, Ferry N. Adv Exp Med Biol. 2015;871:103-30

13. Technology forecast: advanced therapies in late clinical research, EMA approval or clinical application via hospital exemption. Eder C, Wild C. J Mark Access Health Policy. 2019 Apr 19;7(1):1600939

14. Challenges in Advanced Therapy Medicinal Product Development: A Survey among Companies in Europe. Ten Ham RMT, Hoekman J, Hövels AM, Broekmans AW, Leufkens HGM, Klungel OH. Mol Ther Methods Clin Dev. 2018 Oct 11;11:121-130

15. Translational research: crossing the valley of death. Butler D. Nature. 2008 Jun 12;453(7197):840-2.

16. EU Regulatory Pathways for ATMPs: Standard, Accelerated and Adaptive Pathways to Marketing Authorisation. Detela G, Lodge A. Mol Ther Methods Clin Dev. 2019 Jan 29;13:205-232 